\title{
The National Institutes of Health funding for cardiothoracic surgical research
}

Irving L. Kron, MD

See related article on page 392.
From the Department of Surgery, Division of Thoracic and Cardiovascular Surgery, University of Virginia Medical Center, Charlottesville, Va

Received for publication May 9, 2008; accepted for publication June 2, 2008.

Address for reprints: Irving L. Kron, MD, Professor and Chairman, University of Virginia Health System, Department of Surgery, Division of Thoracic and Cardiovascular Surgery, University of Virginia Medical Center, Lee Street, Room 2753, Box 800679, Charlottesville, VA 22908 (E-mail: ilk@virginia.edu).

J Thorac Cardiovasc Surg 2008;136:398-9 $0022-5223 / \$ 34.00$

Copyright $\odot 2008$ by The American Association for Thoracic Surgery

doi:10.1016/j.jtcvs.2008.06.003
$\mathrm{R}$ atcliffe and colleagues have made an important contribution about the state of research for cardiothoracic surgeons (see page 392). They have appropriately concluded that per capita funding by the National Institutes of Health $(\mathrm{NIH})$ for cardiothoracic surgeons is less than that of the NIH as a whole. They have done a very careful analysis of the reasons for this. The bottom line is that there are two major issues.

The first is that there had been a change related to grant review in that surgical grants were reallocated to nonsurgical study sections. The concept here was to have more disease-oriented study sections. In practice, this meant that clinical investigators would not get appropriate peer review. Cardiothoracic surgical research is truly translational research. It takes basic science principles and applies them to the clinical realm. Appropriate peer review comprises surgeons who see and study these clinical problems and know the importance of such applications. Because of this reorganization, surgical grants tended to fair poorly in these nonsurgical study sections. Through the efforts of the Scientific Affairs Committee of The American Association for Thoracic Surgery (AATS), this has been addressed with the NIH leadership. Surgeons will now be allowed to request appropriate study sections if indeed the study section requested review such grants in general. I believe this will make a large difference.

The second issue that the authors have raised is a more difficult one. The problem here is that there are fewer grants being submitted. The authors have suggested that there should be some affirmative action from the NIH to encourage research from cardiothoracic surgeons. In fact, there is a great concern at the NIH about the loss of clinical investigators in general. I think the problem here is more than just one for the NIH, but also for the leadership of cardiothoracic surgery as a whole. This is perhaps the major issue facing us. If there is no scientific investigation by our future faculty, then there will no new technology or advances in our field. Our specialty will stagnate and eventually whither away. I would suggest that this should be a major focus for the thoracic surgical leadership.

The AATS has plans to focus on the development of academic surgeons. These will need to be amplified. Appropriate mentorship for clinical investigators is the most difficult issue facing surgical division and department chairs. The balance between clinical work and scientific investigation is very difficult to achieve. As a matter of fact, this was the major issue discussed at the new members' luncheon at the recent AATS meeting. There is a tremendous emphasis for young faculty members to develop clinical surgical careers. To develop a clinical reputation, one must operate and achieve good results. This is in stark contrast to the needs of the basic science investigator. Indeed, those individuals in basic science departments are full-time investigators and have time to develop their research careers. Therefore, how will this balance be met? For our specialty to develop clinical investigators, we must provide the resources to protect them at least at the beginning of their academic careers while they are developing scientific cooperations. They must learn how to run a laboratory as well as get grant funding. Just protecting time is not enough. Senior leadership of departments and divisions must guarantee that these individuals use the time to develop their scientific careers. To help them to develop their clinical careers at the same time, we must provide them with cases and support 
so that the balance can be met. For some institutions this is easier than for others. Not all institutions are able to provide young investigators appropriate scientific and clinical mentoring. Therefore, our national organizations will somehow have to develop a method for mentoring to occur on a national level.

I must congratulate the authors for bringing this major issue to our attention. I believe further follow-up will be required.

Access to The Journal of Thoracic and Cardiovascular Surgery Online is reserved for print subscribers!

Full-text access to The Journal of Thoracic and Cardiovascular Surgery Online is available for all print subscribers. To activate your individual online subscription, please visit The Journal of Thoracic and Cardiovascular Surgery Online, point your browser to http://www.mosby.com/jtcvs, follow the prompts to activate your online access, and follow the instructions. To activate your account, you will need your subscriber account number, which you can find on your mailing label (note: the number of digits in your subscriber account number varies from 6 to 10 ). See the example below in which the subscriber account number has been circled:

\section{Sample mailing label}

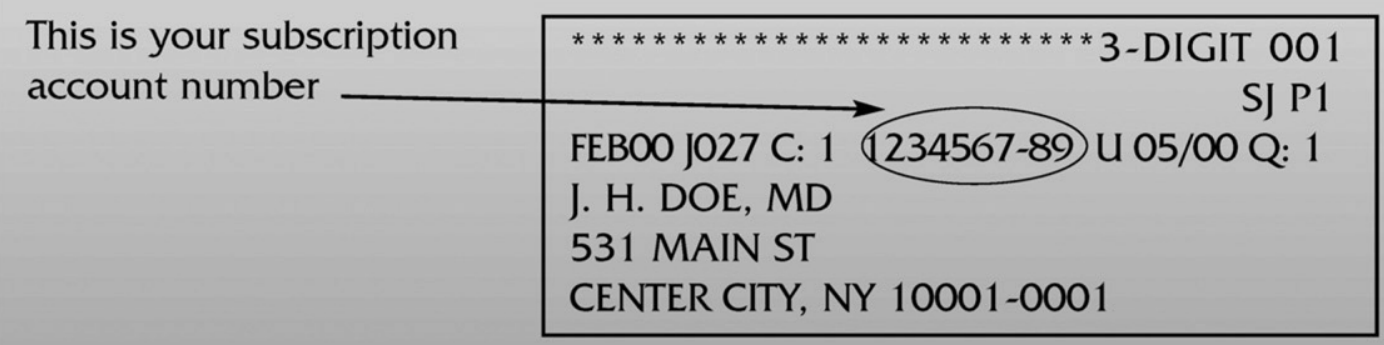

Personal subscriptions to The Journal of Thoracic and Cardiovascular Surgery Online are for individual use only and may not be transferred. Use of The Journal of Thoracic and Cardiovascular Surgery Online is subject to agreement to the terms and conditions as indicated online. 